tiva constituyen la más completa y exacta exégesis de la poesía del Paraguay.

\title{
Gastón Figueirá
}

Eusebio Vela, Tres comedias.-Edición, introducción y notas de Jefferson Rea Spell y Francisco Monterde. México. Imprenta, Universitaria, 1948. xxv-240 pp.

Este tomo contiene tres comedias inéditas de Eusebio Vela: Apostolado en las Indias y martirio de un cacique, Si el amor excede al arte, ni amor ni arte a la prudencia y La pérdida de España. Los manuscritos de las dos primeras se guardan en la Biblioteca Nacional de Madrid; el de la tercera, en el Museo Británico. Exceptuándose estas tres comedias, sólo quedan de su producción teatral catorce títulos que se citan en documentos de aquel período.

$\mathrm{La}$ interesante introducción deja una cabal impresión de Vela como hombre, lo mismo que como empresario, actor y dramaturgo. Nació en Toledo, España, en 1688. Trabajó en los teatros de Madrid, probablemente, a principios del xviI. Tuvo un hermano José (dato que contradice lo que afirma Armando de Maria y Campos en Andanzas y picardias de Eusebio Vela, México, 1944, p. 42), quien ingresó en 1713 a la Compañía del Coliseo de México. Las noticias relativas a su carrera, prueban que gozó de gran popularidad durante su vida, y fué, sin duda, el primer actor y autor dramático de su época en el teatro mexicano. Constantemente se vió ante dificultades económicas y enredos con sus socios y fué perseguido por sus acreedores con procedimientos legales; mas, a pesar de tantas penas, nunca perdió su amor por el teatro. En varias ocasiones tuvo que pedir préstamos, para sufragar los gastos indispensables de la compañía. Cinco niños que abandonaron en diversas épocas, a las puertas de su casa, fueron adoptados y criados como miembros de su familia: otro indicio de que Vera era "hombre de bien." Por ser un simple actor, se le negaba el tratamiento de "señor" y no se le permitía comparecer ante los tribunales para defender sus derechos. Por causas baladíes fué llevado varias veces a la cárcel.

Su comedia Celos aun del aire matan, se representó tres noches consecutivas, durante el mes de diciembre de 1728 , en el palacio virreinal. 
Un año después pusieron en escena El amor excede al arte y Máquina de Arquimedes, que probablemente es también obra de Vela. En el mes de diciembre de 1730 se representó en el palacio su comedia Si el amor excede al arte, ni amor ni arte a la prudencia. En 1731 pudo arrendar el Coliseo por seis años: otra prueba de su popularidad. Al año siguiente escribió Duelos de ingenio y fortuna. La Gazeta de México anunció en 1733 que estaba para imprimirse su comedia El.menor Máximo San Francisco y citó los títulos de otras diez que, hasta ahora, apenas se han mencionado. Durante las temporadas siguientes Vela mostró gran actividad, como actor y como dramaturgo. En 1736 aumentó el personal de su compañía a veinticinco elementos; pero, por no haber cumplido con su promesa de traer actores de España, empezó a pagar una multa. Muerto en Veracruz, el 19 de abril de 1737 , se reçonoció a su viuda, Mariana Tecla, el derecho de conservar en arrendamiento el teatro hasta 1745 .

Las tres comedias reunidas en este tomo difieren mucho entre sí. La primera, Apostolado en las Indias, es única por tratar de sucesos de la historia de la Nueva España. El argumento sigue en su mayor parte los hechos relatados por los cronistas Motolinía, Mendieta, Torquemada y Vetancurt, siendo Mendieta la fuente más probable. La mayor parte de los personajes realmente pertenece a la historia mexicana. La acción tiene lugar en Tlaxcala, poco después de llegar allá los doce misioneros franciscanos que habían venido al Nuevo Mundo a cristianizar a los aborígenes. Fray Martín de Valencia obra un milagro; un cacique indio quema vivo a su hijo convertido al cristianismo, y Santiago, montado en un corcel, ayuda a los españoles a ganar la victoria. Si el amor excede al arte, ni amor ni arte a la prudencia se inspiró en Las aventuras de Telémaco, de Fenelón. Vela se permitió algunas libertades; sobre todo, en lo que se relaciona con los personajes secundarios. La pérdida de España tiene como base la famosa leyenda de Rodrigo. No es una imitación de El último godo, de Lope de Vega; la influencia más directa parece provenir de la Verdadera bistoria del Rey don Rodrigo, por Miguel de Luna.

Los editores, basando sus opiniones en las tres comedias de este tomo, observan "que en ninguna de ellas hay algo que las distinga de las escritas, en el mismo siglo xvIII, por los continuadores e imitadores de Lope, y, especialmente, de Calderón, entre los cuales debe, sin duda, situarse a Vela." Algunos rasgos de esas obras son lo sobrenatural y fantástico; largos parlamentos llenos de frases huecas y un estilo oratorio y mestafórico. El gracioso proporciona el humorismo. Por lo visto, 
el romance fué el verso preferido por Vela. Este dramaturgo merece la gratitud de México, por haber llevado su historia y tradición al teatro. En esta edición, Spell y Monterde modernizaron la puntuación y la acentuación y corrigieron las faltas de ortografía. Conservaron, por su valor fonético, algunas palabras anticuadas. Nuevos datos procedentes del Archivo de Notarías y el Archivo General de la Nación, en la ciudad de México, ayudan a trazar un cuadro biográfico mucho más completo y verídico de Vela. Los textos de las comedias, lo mismo que la introducción, están bien documentados; las notas eruditas resuelven los problemas del texto y aclaran los hechos históricos. Nadie que pretenda conocer la evolución del teatro mexicano en general y en la primera mitad del siglo xvin en particular, puede prescindir de esta edición de las Tres comedias de Eusebio Vela, libro excelente en todos sentidos.

\section{Harvey L. Johnson, Indiana University, Bloomington, Indiana.}

Eduardo Barrios, Los hombres del hombre.-Editorial Nascimento, Santiago, Chile. 1950. 317 pp,

Después de Gran señor y rajadiablos — más que novela, cordial biografía-, Eduardo Barrios vuelve a recorrer el hondo cauce de la novela psicológica, en el cual había profundizado, desde $E l$ niño que enloqueció de amor, con Los bombres del bombre, novela terminada a fines de 1949 y publicada en 1950 .

Lecturas de tipo académico: monografías y tesis, de revisión inaplazable, obligan a quien desempeña una cátedra. a reservar para los breves finales de tareas didácticas: las vacaciones anuales, aquellas lecturas más gratas, largo tiempo aplazadas, por obligaciones ineludibles.

Los libros selectos, pospuestos en su lectura por las tareas docentes, se van apilando ante los ojos -nuevo suplicio tantálico--, y el profesor de literatura que hace crítica literaria accidentalmente, pasa por descortés y olvidadizo, a pesar suyo.

Así, esta obra del admirado novelista chileno, hizo un viaje redondo, en el que acompañó varias semanas a quien escribe esta nota, antes de encontrar horas propicias para su lectura. 